\title{
CONGENITAL ORBITAL TERATOMA: A RARE CASE REPORT WITH REVIEW OF LITERATURE
}

Tamil Arasi D. S1, Surya Babu Sunkesula², Lingeswara Rao B³, Varra Lakshmi4, C. Mallikarjun ${ }^{5}$

\section{HOW TO CITE THIS ARTICLE:}

Tamil Arasi D. S, Surya Babu Sunkesula, Lingeswara Rao B, Varra Lakshmi, C. Mallikarjun. "Congenital Orbital Teratoma: A Rare Case Report with Review of Literature". Journal of Evolution of Medical and Dental Sciences 2015; Vol. 4, Issue 06, January 19; Page: 1080-1083, DOI: 10.14260/jemds/2015/153

ABSTRACT: Congenital teratomas represent derivatives of all three germinal cell layers, arranged in varying degree of complexity and they rarely affect the orbit. We report a rare case of unilateral congenital orbital teratoma with marked proptosis presenting at birth.

KEYWORDS: congenital orbital teratoma, germinal cell layers, proptosis.

INTRODUCTION: The word "teratoma" means "monstrous growth" in Greek. Teratomas are composed of derivatives of all three germinal layers, arranged in haphazard manner.[1,2] We are reporting a rare case of congenital orbital teratoma in a newborn baby.

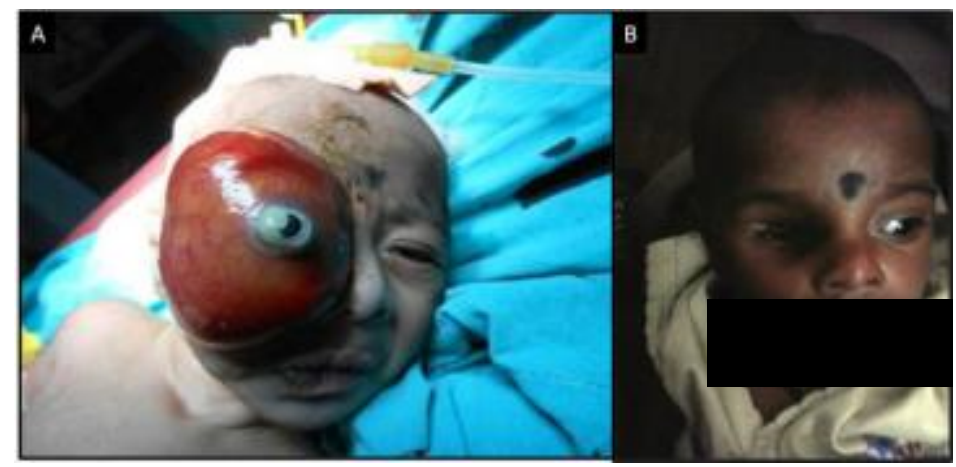

FIG. 1

Figure 1 shows (A) extreme proptosis with forward displacement of the right eye in an otherwise normal full-term newborn baby (B) post-operative photograph after exenteration.

CASE REPORT: A full term male newborn baby of normal, uneventful vaginal delivery had a fleshy mass in the place of the right eye. Physical examination revealed marked proptosis of the right eye. The eyeball was embedded within the mass. Ocular mobility was restricted in all directions. Left eye was normal. Routine hematological examination and serum chemistry revealed no abnormality. Radiologically, the mass was confined to the right orbit with solid and cystic areas and there was no intracranial extension. Considering the size and extent of the tumor, an exenteration with reconstruction of the eyelids was done. Post-operative course was uneventful.

Grossly, the tumor was well encapsulated measuring $6 \times 5 \times 3 \mathrm{~cm}$. Cut surface showed greywhite to yellowish solid areas and cystic areas. Microscopically, multiple sections of the specimen studied showed derivatives of all the three germinal layers in the form of adipose tissue, cartilage, cystic areas lined by simple cuboidal to stratified squamous epithelium and dermal appendages. Areas with glandular and mature neuroglial differentiation were seen. No immature element was seen. A final diagnosis of a mature teratoma was made. 


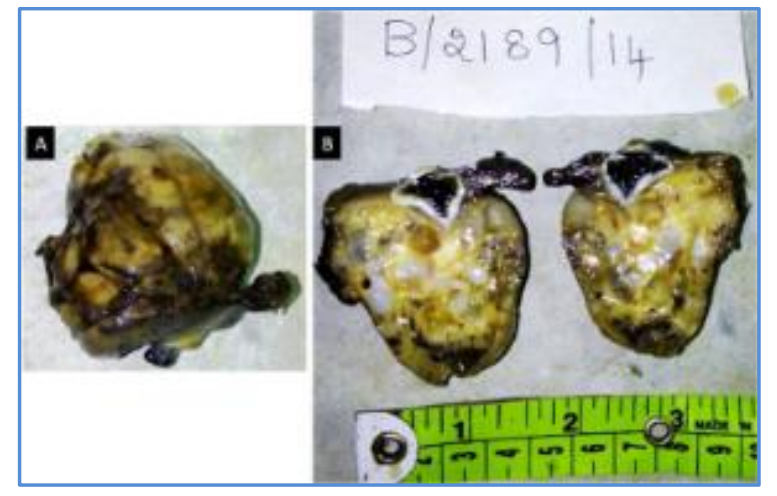

\section{FIG. 2}

Figure 2 shows gross appearance of the orbital mass of right eye: (A) external surface and (B) cut surface.

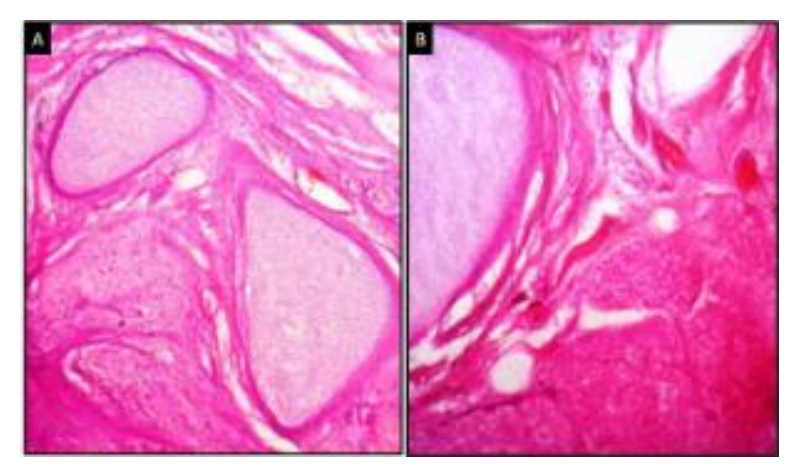

FIG. 3

Figure 3 shows photomicrographs showing (A) cartilage and muscle tissue (B) cartilage and adipose tissue (H\&E, x100).

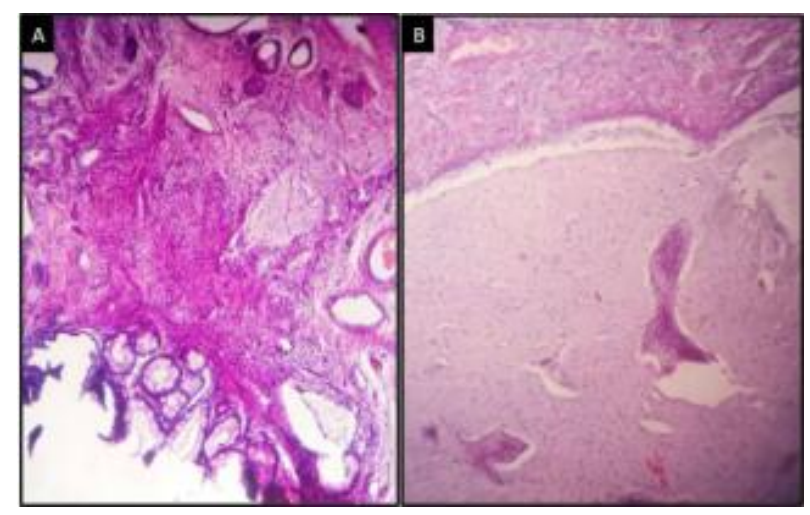

FIG. 4

Figure 4 shows photomicrographs showing (A) intestinal epithelium at the bottom (B) mature glial tissue (H\&E, x100). 


\section{CASE REPORT}

DISCUSSION: Ocular mass at birth is uncommon and a teratoma is a rare cause. [3] The first case of orbital teratoma was reported by Holmes in 1863.[4] Barber et al in 1974 reviewed the literature and compiled a total of 54 cases.[5]

The "organizer" theory modified by Krafka provides a tenable explanation.[6,7] This theory discusses interference with the normal development of the growth center of the embryo (Stated to be the primitive streak in man) allowing the development of secondary growth center. Migration of this center to different portions of the embryo leads to the occurrence of a teratoma. The rare occurrence of orbital teratomas may be the result of the greater distance of the primordial of the orbit and eye and the primitive streak.

Duke-Elder ${ }^{[8]}$ has classified teratomas of the orbit as follows:

1) A complete fetus implanted in the orbit (Orbitopagus parasiticus)

2) A portion of a second fetus in the orbit

3) A tumor consisting of all three germinal layers

4) Tumors containing representatives of two germinal layers only

5) Tumors containing representatives of one layer only.

Jensen ${ }^{[9]}$ proposed that only a tumor derived from all three germinal layers should be called a teratoma. If the tumor is composed of tissue from only two germinal layers, it should be termed teratoid. Tumors with tissue from only one germinal layer in the orbit, i.e. dermoid cyst are choristomas.

A review of the literature showed a female-to-male ratio of 2: 1 and a slight preponderance to the left side. Only two cases were bilateral.[5] Two instances of malignant teratoma have been reported.[10,11] Teratoma is considered malignant when the tissue is embryonal or immature in nature. Our case is a male newborn baby with right sided orbital teratoma. It is a benign mature teratoma showing components of all three germinal layers without any immature elements.

Clinically, it is difficult to distinguish teratomas from other benign and malignant neoplasms. Differential diagnosis includes other congenital anomalies such as dermoid cyst, encephalocele, meningocele, and cystic eye; neoplasms such as neuroblastoma, neurofibroma, hemangioma and lymphangioma; and other ocular diseases such as congenital glaucoma, retrobulbar hemorrhage and hematoma. ${ }^{[10,12]}$

The surgical treatment of these lesions almost always has been effective. Surgeons now recommend early surgery despite the difficulty in making the diagnosis preoperatively.[13] Recurrence of the incompletely removed teratoma has been reported.

Rapid enlargement of the teratoma after birth is characteristic. The solid portions increase in size, and the amount of cystic fluid increases. When untreated for a period of months, the tumor may become enormous. With the expansion of the mass, the eye becomes exposed, compressed and eventually perforated.

In our case of congenital orbital teratoma, histological examination revealed components from all three germinal layers and no sign of malignancy. Exenteration was performed and the postoperative period was uneventful. 


\section{REFERENCES:}

1. Ferry AP. Teratoma of the orbit: A report of two cases. Surv Ophthalmol. 1965; 10: 434-42.

2. Simonsen AH, Sogaard H. Teratoma orbitae. Report of a case. Acta Opthalmol Copenh. 59: 308316, 1981.

3. Heerema-McKenney A1, Harrison MR, Bratton B, Farrell J, Zaloudek C (2005), congenital teratoma: a clinicopathologic study of 22 fetal and neonatal tumors. Am J Surg Pathol 29: 29-38.

4. Holmes, T. (1863): Congenital tumor removed from the orbit. Trans. Pathol. Soc. London. 14: 248.

5. Barber JC, Barber LF, Dupont G et al. (1974): Congenital orbital teratoma. Arch, opthalmol. 91: 45-48.

6. Budde M (1926) Über die Genese den Fetal Inklusionen. Beitr Path Anat 75: 357-398.

7. Krafka J: Teratoma: an explanation of its cause based on the organizer theory of embryology. Arch Pathol 21: 756, 1936.

8. Duke Elder S. System of Ophthalmology, Normal and Abnormal Development, Congenital deformities.Vol 3. St Lois: CV Mosby; 1963. pp. 967-4. Part 2.

9. Jensen OA. Teratoma of the orbit. Acta Ophthalmol (Copenh). 1969; 47(2): 317-27.

10. Ide CH, Davis WE, Black SP. Orbital teratoma. Arch Ophthalmol. 1978 Nov; 96(11): 2093-6.

11. Garden JW, McManis JC. Congenital orbital-intracranial teratoma with subsequent malignancy: case report. Br J Ophthalmol. 1986 Feb; 70(2): 111-3.

12. Levin ML, Leone CR Jr, Kincaid MC. Congenital orbital teratomas. Am J Ophthalmol. 1986 Oct 15; 102(4): 476-81.

13. Bartholdson L, Johanson B, Mortenson K. Congenital teratoma of the orbit. Case report: mainly clinical and therapeutic aspects. Scand J Plast Reconstr Surg. 1967; 1(2): 90-6.

\section{AUTHORS:}

1. Tamil Arasi D. S.

2. Surya Babu Sunkesula

3. Lingeswara Rao B.

4. Varra Lakshmi

5. C. Mallikarjun

\section{PARTICULARS OF CONTRIBUTORS:}

1. Professor and Head, Department of Pathology, Kurnool Medical College, Kurnool, Andhra Pradesh.

2. Associate Professor, Department of Pathology, Kurnool Medical College, Kurnool, Andhra Pradesh.

3. Senior Resident, Department of Pathology, Kurnool Medical College, Kurnool, Andhra Pradesh.
4. Assistant Professor, Department of Pathology, Kurnool Medical College, Kurnool, Andhra Pradesh.

5. Tutor, Department of Pathology, Kurnool Medical College, Kurnool, Andhra Pradesh.

NAME ADDRESS EMAIL ID OF THE CORRESPONDING AUTHOR:

Dr. Tamil Arasi D. S, Professor and Head, Department of Pathology, Kurnool Medical College, Kurnool - 518002, Andhra Pradesh. E-mail: hodpathkmcknl@gmail.com

Date of Submission: 31/12/2014. Date of Peer Review: 01/01/2015. Date of Acceptance: 10/01/2015. Date of Publishing: 19/01/2015. 